\title{
Candidacidal activity of Crohn's disease neutrophils
}

\author{
F T Curran, D J Youngs, R N Allan, M R B Keighley
}

\begin{abstract}
The ability of normal and Crohn's disease neutrophils to kill Candida albicans has been studied using neutrophils isolated from peripheral blood and suspended in phosphate buffered saline at $5 \times 10^{6}$ cells per $\mathrm{ml}$. C albicans was grown to a stationary phase in broth culture and suspended in phosphate buffered saline at $10^{\prime}$ organisms $/ \mathrm{ml}$. Neutrophils and Candida were then incubated together at $37^{\circ} \mathrm{C}$ in a shaking water bath in the presence of fresh serum. At 30 and 60 minutes samples were withdrawn, neutrophils lysed, and Candida survival assessed by colony counting. Results were compared with control suspensions of Candida incubated with serum alone. After 30 and 60 minutes in the presence of autologous serum normal neutrophils had killed significantly more Candida than Crohn's disease neutrophils (mean (SD) $61.0(16.7) \%$ v 40.5 (16.2)\% at 30 minutes, $\mathbf{p}<0.0001 ; 83.2(7) \%$ v $70.8) 16) \%$ at 60 minutes, $p<0.005)$. The results did not alter significantly when normal neutrophils were incubated with Candida in the presence of Crohn's disease serum instead of normal serum. When Crohn's disease neutrophils were incubated with Candida in the presence of normal serum instead of autologous serum there was some improvement in candidacidal ability at 30 minutes $(48.9(20.6) \%$ $v 40.5(16.2) \%, p<0.03)$ but not at 60 minutes. Phagocytosis, measured using a radiometric assay, was normal. Neutrophils from patients with Crohn's disease have an impaired ability to kill this granuloma provoking organism. It is not due to serum inhibitors or defective phagocytosis.
\end{abstract}

The inactivation of invading micro-organisms is the most important function of the neutrophil. Although various abnormalities of neutrophil function have been reported in Crohn's disease, ${ }^{1}$ their capacity to kill granuloma provoking organisms has not been evaluated.

This study was designed to investigate the ability of Crohn's disease neutrophils to kill Candida albicans. The organism was chosen for study because it is present in the gastrointestinal tract of $14-47 \%$ of the healthy population ${ }^{23}$ and causes chronic inflammatory diseases, such as chronic mucocutaneous candidiasis, and leads to granuloma formation. ${ }^{3}$ It may also cause enteritis ${ }^{4}$ and allergic colitis. ${ }^{56}$ It is a convenient organism to culture compared to other organisms responsible for causing chronic inflammatory conditions. Whereas $C$ albicans can be cultured in two to three days, mycobacteria, for example, require four to 12 weeks. It is a relatively safe organism to handle and is the species most resistant to killing by neutrophils.'

Phagocytosis was studied using a sensitive radiometric assay to determine whether impairment of candidacidal activity could be a result of this.

\section{Methods}

\section{PREPARATION OF ORGANISMS}

$C$ albicans from the same source were used in all experiments. The organisms were isolated from the faeces of a healthy woman who was taking no drugs. The organism was maintained in stock culture on a slope of malt extract agar (Oxoid) at room temperature. When required, a sample of the organisms was inoculated into approximately $50 \mathrm{ml}$ Sabouraud liquid medium (Oxoid) and grown to a stationary phase for three to five days at $30^{\circ} \mathrm{C}$. The organisms were washed twice in Dulbecco's B phosphate buffered saline (PBS), centrifuged at $1500 \mathrm{~g}$ for 10 minutes after each wash, counted in an improved Neubauer haemocytometer, and suspended in PBS at a concentration of $10^{7}$ organisms per ml. Freshly cultured organisms were used in all tests.

\section{PREPARATION OF NEUTROPHILS}

Neutrophils were isolated from fresh venous blood using discontinuous density gradients of Percoll (Pharmacia) as follows. An iso-osmotic stock solution of Percoll was made by adding 1 part $1.5 \mathrm{M}$ saline to 9 parts Percoll (resulting density $1 \cdot 123 \mathrm{~g} / \mathrm{ml}$ ). Stock Percoll was further diluted with $0.15 \mathrm{M}$ saline to densities of $1.070 \mathrm{~g} /$ $\mathrm{ml}^{8}$ and $1.097 \mathrm{~g} / \mathrm{ml}^{9}$ for the separation of white cells. In a sterile universal container was placed $6 \mathrm{ml}$ Percoll of density $1.097 \mathrm{~g} / \mathrm{ml}$, then $4 \mathrm{ml}$ Percoll of density $1.070 \mathrm{~g} / \mathrm{ml}$ was carefully layered on top avoiding mixing at the interphase.

Five $\mathrm{ml}$ heparinised blood was diluted with an equal volume of $0.15 \mathrm{M}$ saline and carefully layered on top of the Percoll in the same way. The tube was centrifuged at $200 \mathrm{~g}$ for 25 minutes, to ensure isopycnic banding of cells at the relevant interphases; granulocytes were suspended between the two layers of Percoll. They were removed with a pipette and washed twice in PBS and centrifuged at $1500 \mathrm{~g}$ for 10 minutes after each wash. Any contaminating erythrocytes were lysed by hypotonic shock treatment by resuspending the cells in tris-ammonium chloride for 10 minutes before the second wash. Neutrophils were counted in an improved Neubauer chamber and resuspended in PBS at concentrations of $5 \times 10^{6}$ cells per ml. All neutrophil suspensions were at least $95 \%$ pure and viability, assessed by trypan blue exclusion tests, ${ }^{7}$ was $98 \%$.

\section{CANDIDACIDAL ASSAY}

The study was performed in two parts using 
TABLE I Subject data-candidacidal assay

\begin{tabular}{llll}
\hline & Healthy subjects & \multicolumn{2}{l}{ Crohn's disease } \\
\hline Autologous serum: & & & \\
No & 20 & 30 & \\
Mean (SD) age (years) & $47(18)$ & $45(16)$ & \\
Sex & $13 \mathrm{M}, 7 \mathrm{~F}$ & $10 \mathrm{M}, 20 \mathrm{~F}$ & \\
Disease activity & - & Quiescent & 19 \\
No taking steroid treatment & - & Active & 11 \\
'Crossed' serum: & & 4 & \\
No & 15 & & \\
Mean (SD) age (years) & $45(18)$ & 25 & \\
Sex & $8 \mathrm{M}, 7 \mathrm{~F}$ & $89(14)$ & \\
Disease activity & - & Quiescent & 15 \\
& & Active & 10 \\
No taking steroid treatment & - & 4 & \\
Phagocytosis assay: & & & \\
No & 20 & 20 & \\
Mean (SD) age (years) & $40(15)$ & $38(13)$ & \\
Sex & $9 \mathrm{M}, 11 \mathrm{~F}$ & $14 \mathrm{M}, 6 \mathrm{~F}$ & \\
Disease activity & - & Quiescent & 12 \\
No taking steroid treatment & - & Active & 8 \\
\hline
\end{tabular}

fresh serum, either autologous or 'crossed' - that is, normal neutrophils with Crohn's disease serum and vice versa. With autologous serum, 20 healthy subjects and 30 patients with Crohn's disease were studied; with crossed serum there were 15 and 25 respectively. Details of subjects are summarised in Table I. Four patients were taking steroids; none was taking sulphasalazine. Crohn's disease activity was assessed using the method of Harvey and Bradshaw. ${ }^{10}$

A $0.5 \mathrm{ml}$ neutrophil suspension, $0.25 \mathrm{ml} C$ albicans, and $0.25 \mathrm{ml}$ fresh serum were brought to $37^{\circ} \mathrm{C}$ and mixed in a stoppered polystyrene test tube. Tubes were laid on their sides in a shaking water bath at $37^{\circ} \mathrm{C}$ so that the contents flowed continually from one end of the tube to the other during each cycle. A control tube containing $C$ albicans, fresh serum, and $0.5 \mathrm{ml}$ PBS instead of neutrophils was included in each test.

At time 0 (immediately after mixing) a $10 \mu \mathrm{l}$ aliquot was withdrawn from the control tube for an initial colony count, so that the exact number of viable organisms used in each test was known.

Two time points were included for each assay. At 30 and 60 minutes $10 \mu \mathrm{l}$ aliquots were

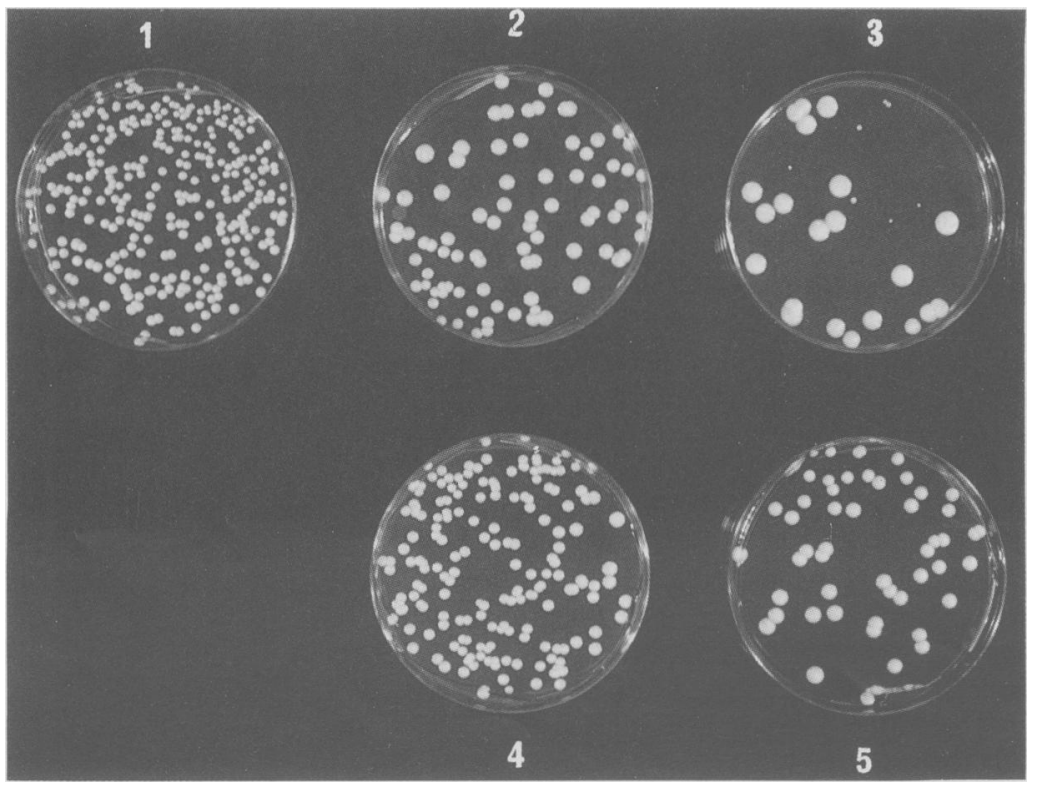

Figure 1: Candida albicans on agar plates after 3 days' incubation: 1. At time $0 ; 2$. After 30 minutes with normal neutrophils; 3 . After 60 minutes with normal neutrophils; 4 . After 30 minutes with Crohn's neutrophils; 5 . After 60 minutes with Crohn's neutrophils. withdrawn from each tube (control, normal, and Crohn's disease) and allowed to stand for at least 10 minutes in $10 \mathrm{ml}$ sterile distilled water to lyse neutrophils and release ingested organisms. This time was adequate to lyse all neutrophils, which was confirmed microscopically on several occasions - after centrifuging the water no neutrophils could be identified in the deposit Each aliquot was serially diluted to $1 \times 10^{4}$ and $1 \times 10^{5}$ of the initial concentration using sterile distilled water and sterile glass containers. One $\mathrm{ml}$ of both the $10^{4}$ and $10^{5}$ dilutions was spread on malt extract agar and incubated at $30^{\circ} \mathrm{C}$ for two to three days. The number of colonies of $C$ albicans on the plates (Fig 1) was counted using an illuminated colony counter. The $10^{4}$ dilution plate was normally counted but if the number of colonies was excessive the $10^{5}$ dilution plate was used instead. Any $10^{5}$ plate used contained at least 15 colonies.

The percentage killing was calculated using the formula:

$\%$ of yeast killed $=$

$$
100-\left(\frac{(\text { No of colonies at } 30 \text { or } 60 \text { minutes }) \times 100}{(\text { No of colonies at time } 0)}\right)
$$

The percentage of Candida remaining on control plates at 30 and 60 minutes was also calculated to ensure that neither normal nor Crohn's disease serum alone had candidacidal activity, using the formula:

$\%$ candida remaining on control plate $=$

(No of 'control' colonies at 30 or 60 minutes)

(No of colonies at time 0 ) $\times 100$

\section{INTERASSAY VARIABILITY}

Three assays were performed in triplicate on different days. The numbers of Candida colonies on each plate are given in Table II. The variance, calculated using the formula:

$$
\text { variance }=\frac{\text { standard deviation }}{\text { mean }} \times 100,
$$

was $9.5 \%$ at 30 minutes and $11 \cdot 4 \%$ at 60 minutes.

PHAGOCYTOSIS ASSAY

Twenty healthy subjects and 20 patients with Crohn's disease were studied. Details are summarised in Table I. Neutrophils were suspended at $8 \times 10^{5}$ cells $/ \mathrm{ml}$ PBS and $C$ albicans at $4 \times 10^{\circ}$ organisms $/ \mathrm{ml}$ PBS, a Candida:neutrophil ratio of 5:1. A $0.5 \mathrm{ml}$ neutrophil suspension, $0.5 \mathrm{ml}$ Candida suspension, and $50 \mu \mathrm{l}$ autologous

TABLE II Interassay variability

\begin{tabular}{lll}
\hline & \multicolumn{2}{l}{ No of Candida colonies } \\
\cline { 2 - 3 } & 30 minutes & 60 minutes \\
\hline Assay 1 & 71 & 51 \\
& 80 & 51 \\
Assay 2 & 73 & 47 \\
& 44 & 30 \\
Assay 3 & 40 & 27 \\
& 52 & 32 \\
& 71 & 27 \\
& 69 & 19 \\
\hline
\end{tabular}


serum were incubated at $37^{\circ} \mathrm{C}$ in a shaking water bath. The tubes were laid on their sides so that the contents continually flowed from one end of the tube to the other during each cycle. All experiments were performed in duplicate and a control tube containing $0.5 \mathrm{ml}$ PBS instead of neutrophils was included in each assay. During this incubation Candida were phagocytosed by neutrophils.

After incubation $0.2 \mathrm{ml}$ aliquots were withdrawn from each tube, tests, and controls, and transferred into microtitre wells containing $3 \cdot 6$ $\mu l\left[5,6-{ }^{3} \mathrm{H}\right]$ uridine (specific activity $46 \mathrm{Ci} / \mathrm{mmol}$, Amersham International) made up to $20 \mu \mathrm{l}$ with PBS. The microtitre plate was incubated at $37^{\circ} \mathrm{C}$ for one hour. During this time Candida which had not been phagocytosed incorporated ${ }^{3} \mathrm{H}$ uridine.

After the second incubation $0.1 \mathrm{ml}$ aliquots were withdrawn from each microtitre well after mixing and transferred to a Whatman GF-B filter (pore size $1 \mu \mathrm{m}$ ) prewetted with PBS. Each filter was washed with approximately $8 \mathrm{ml}$ sterile distilled water under suction from a stream of water to remove free radioactivity, so as to leave only Candida-associated radioactivity on the filter. To confirm that the wash was sufficient to remove all free radioactivity, ${ }^{3} \mathrm{H}$-uridine was placed on four filters and washed precisely as described; only background radioactivity could be detected on them.

The filters were dried overnight, placed in scintillation fluid, and the radioactivity counted. To check that no Candida passed through the filter the filtrate was centrifuged and the pellet examined under a microscope; it contained a few fragments of glass fibre from the filter but no organisms.

The mean number of Candida phagocytosed per neutrophil (the phagocytic index), was calculated using the following formula:

Phagocytic index $=$

$$
\begin{gathered}
\left(1-\frac{(\mathrm{dpm} \text { for Candida }+ \text { neutrophils })}{(\mathrm{dpm} \text { for Candida alone })}\right) \times \\
\frac{\text { No of Candida }}{\text { No of neutorphils }}
\end{gathered}
$$

where $\mathrm{dpm}=$ disintegrations per minute.

\section{STATISTICAL ANALYSIS}

Results were analysed using the Wilcoxon rank sum test and are expressed as mean (SD).

\section{Results}

CANDIDACIDAL ACTIVITY

The percentages of $C$ albicans killed at 30 and 60 minutes by normal and Crohn's disease neutrophils in autologous serum and crossed serum are shown in Figures 2 and 3, and Tables III and IV. After 30 minutes normal neutrophils had killed significantly more Candida (mean (SD) 61 $(16.7) \%)$ than Crohn's disease neutrophils (40.5 $(16.2) \%)(p<0.0001)$. After 60 minutes the proportion of Candida killed had increased but was

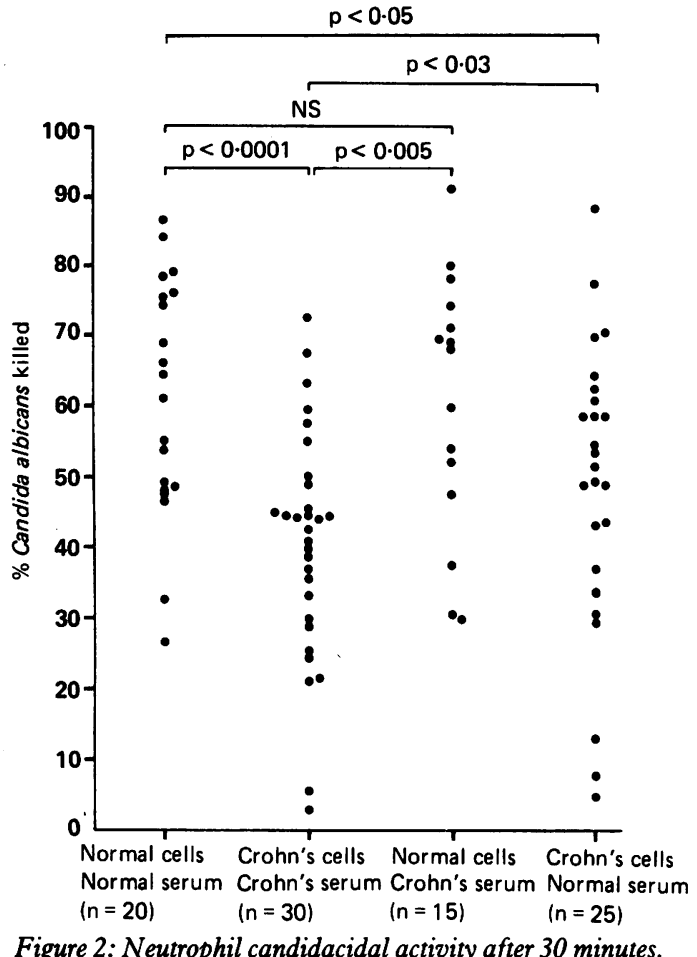

still significantly greater using normal neutrophils (83.2 (7)\%) than Crohn's disease neutrophils $(70.8(16) \%)(\mathrm{p}<0.005)$.

When normal neutrophils were incubated with Crohn's disease serum instead of normal serum the mean killing ability was not significantly altered after either 30 minutes $60 \cdot 8(18 \cdot 4) \%$ in Crohn's disease serum v 61 (16.7)\% in normal serum) or 60 minutes $(78 \cdot 7(8.5) \%$ v $83.2(7) \%)$ (Table IV).

After 30 minutes in normal serum the mean killing ability of Crohn's disease neutrophils improved from $40.5(16.2) \%$ to $48.9(20.6) \%$ $(\mathrm{p}<0.03)$, but was still lower than that of normal neutrophils in normal serum (61 (16.7)\% $(p<0.05)$. At 60 minutes this improvement in killing ability could no longer be shown $(73 \cdot 7$

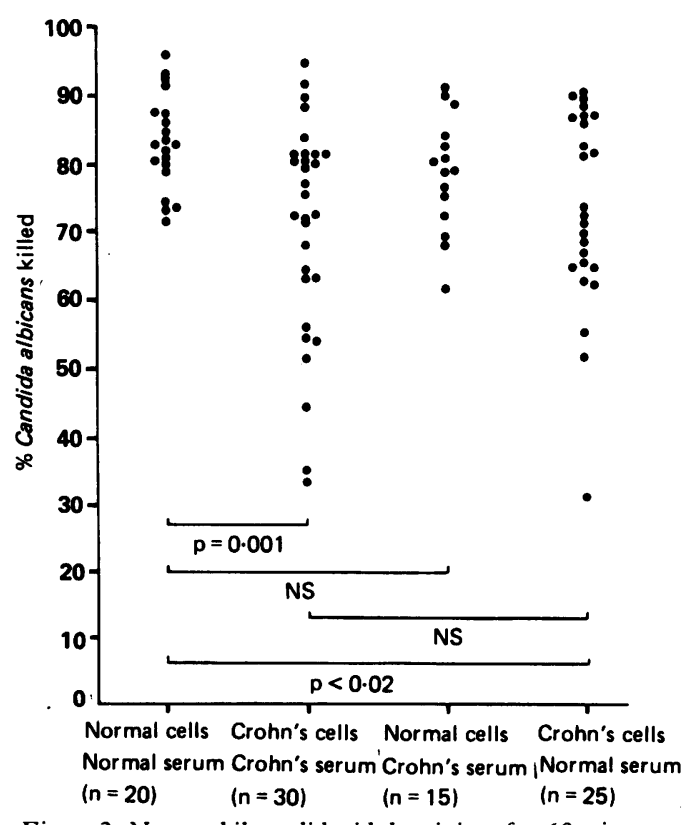

Figure 3: Neutrophil candidacidal activity after 60 minutes. 
TABLE III Percentages of Candida albicans killed

\begin{tabular}{|c|c|c|c|c|}
\hline & \multicolumn{2}{|c|}{$\begin{array}{l}\text { Normal neutrophils } \\
\text { in normal serum }\end{array}$} & \multicolumn{2}{|c|}{$\begin{array}{l}\text { Crohn's neutrophils } \\
\text { in Crohn's serum }\end{array}$} \\
\hline & $30 \mathrm{~min}$ & $60 \min$ & $30 \mathrm{~min}$ & $60 \min$ \\
\hline $\operatorname{Mean}(\mathrm{SD})$ & $\begin{array}{l}75 \cdot 5 \\
78 \cdot 4 \\
64 \cdot 4 \\
69 \cdot 1 \\
79 \cdot 2 \\
53 \cdot 7 \\
48 \cdot 0 \\
32 \cdot 5 \\
49 \cdot 2 \\
86 \cdot 6 \\
66 \cdot 1 \\
80 \cdot 4 \\
61 \cdot 0 \\
75 \cdot 9 \\
55 \cdot 2 \\
46 \cdot 7 \\
48 \cdot 7 \\
26 \cdot 8 \\
47 \cdot 7 \\
74 \cdot 4\end{array}$ & $\begin{array}{l}96 \cdot 1 \\
82 \cdot 0 \\
80 \cdot 0 \\
73 \cdot 2 \\
87 \cdot 3 \\
81 \cdot 1 \\
86 \cdot 1 \\
87 \cdot 9 \\
82 \cdot 9 \\
92 \cdot 4 \\
82 \cdot 7 \\
91 \cdot 5 \\
85 \cdot 0 \\
83 \cdot 4 \\
73 \cdot 9 \\
71 \cdot 3 \\
78 \cdot 9 \\
80 \cdot 4 \\
73 \cdot 8 \\
93 \cdot 1\end{array}$ & $\begin{array}{l}38 \cdot 5 \\
44 \cdot 7 \\
44 \cdot 0 \\
40 \cdot 8 \\
21 \cdot 2 \\
5 \cdot 6 \\
36 \cdot 8 \\
63 \cdot 2 \\
44 \cdot 2 \\
55 \cdot 0 \\
33 \cdot 2 \\
30 \cdot 0 \\
39 \cdot 7 \\
48 \cdot 8 \\
35 \cdot 8 \\
44 \cdot 6 \\
72 \cdot 3 \\
59 \cdot 6 \\
45 \cdot 4 \\
67 \cdot 7 \\
28 \cdot 9 \\
21 \cdot 5 \\
50 \cdot 0 \\
57 \cdot 7 \\
3 \cdot 0 \\
44 \cdot 3 \\
25 \cdot 3 \\
24 \cdot 7 \\
44 \cdot 9 \\
42 \cdot 7 \\
40 \cdot 5(16 \cdot 2)\end{array}$ & $\begin{array}{l}51 \cdot 4^{\star} \\
79 \cdot 3 \\
68 \cdot 0 \\
64 \cdot 4^{\star} \\
33 \cdot 6^{\star} \\
81 \cdot 6^{\star} \\
44 \cdot 5 \\
54 \cdot 5 \\
63 \cdot 1^{\star} \\
71 \cdot 9^{\star} \\
72 \cdot 6 \\
71 \cdot 6 \\
80 \cdot 4^{\star} \\
80 \cdot 2 \\
81 \cdot 7 \\
92 \cdot 0 \\
81 \cdot 7 \\
81 \cdot 5 \\
72 \cdot 3 \\
94 \cdot 9 \\
75 \cdot 3 \\
63 \cdot 2^{\star} \\
53 \cdot 9^{\star} \\
80 \cdot 5 \\
35 \cdot 2 \\
77 \cdot 0 \\
56 \cdot 0 \\
90 \cdot 0^{\star} \\
88 \cdot 7^{\star} \\
84 \cdot 1^{\star} \\
70 \cdot 8(16 \cdot 0)\end{array}$ \\
\hline
\end{tabular}

$\star$ Denotes patient with active disease.

$(14.6) \%$ in normal serum and $70.8(16) \%$ in Crohn's disease serum, not significant).

These findings were independent of disease activity (Figs 4 and 5, Tables III and IV).

Neither normal nor Crohn's disease serum seemed to have candidacidal activity. When compared to colony counts at time 0 , the proportions of Candida colonies remaining after 30 minutes in normal serum was $91 \cdot 2(14 \cdot 3) \%$ and in Crohn's disease serum $97 \cdot 7(8 \cdot 5) \%$. After 60 minutes the results were $92 \cdot 0(17 \cdot 2) \%$ in normal serum and $92 \cdot 1(9 \cdot 4) \%$ in Crohn's disease serum



Figure 4: Crohn's disease neutrophil candidacidal activity at 30 minutes related to disease activity. ' $s$ ' denotes patient on steroids.
TABLE IV Percentages of Candida albicans killed

\begin{tabular}{|c|c|c|c|c|}
\hline & \multicolumn{2}{|c|}{$\begin{array}{l}\text { Normal neutrophils } \\
\text { in Crohn's serum }\end{array}$} & \multicolumn{2}{|c|}{$\begin{array}{l}\text { Crohn's neutrophils } \\
\text { in normal serum }\end{array}$} \\
\hline & $30 \mathrm{~min}$ & $60 \mathrm{~min}$ & $30 \mathrm{~min}$ & $60 \min$ \\
\hline & $\begin{array}{l}30 \cdot 8 \\
69 \cdot 2 \\
52 \cdot 1 \\
30 \cdot 0 \\
91 \cdot 1 \\
68 \cdot 1 \\
80 \cdot 0 \\
54 \cdot 0 \\
47 \cdot 8 \\
78 \cdot 0 \\
74 \cdot 1 \\
71 \cdot 0 \\
69 \cdot 2 \\
59 \cdot 5 \\
37 \cdot 7\end{array}$ & $\begin{array}{l}82 \cdot 8 \\
81 \cdot 1 \\
78 \cdot 9 \\
61 \cdot 7 \\
90 \cdot 2 \\
89 \cdot 2 \\
84 \cdot 3 \\
69 \cdot 3 \\
75 \cdot 1 \\
79 \cdot 2 \\
91 \cdot 7 \\
80 \cdot 3 \\
76 \cdot 6 \\
68 \cdot 2 \\
72 \cdot 2\end{array}$ & $\begin{array}{l}53 \cdot 6 \\
58 \cdot 8 \\
77 \cdot 3 \\
30 \cdot 8 \\
61 \cdot 0 \\
58 \cdot 9 \\
43 \cdot 3 \\
49 \cdot 6 \\
88 \cdot 4 \\
34 \cdot 4 \\
70 \cdot 0 \\
64 \cdot 6 \\
58 \cdot 7 \\
51 \cdot 5 \\
8 \cdot 0 \\
62 \cdot 7 \\
54 \cdot 8 \\
13 \cdot 0 \\
70 \cdot 4 \\
44 \cdot 0 \\
49 \cdot 0 \\
29 \cdot 4 \\
5 \cdot 0 \\
49 \cdot 0 \\
37 \cdot 1 \\
48 \cdot 9(20 \cdot 6)\end{array}$ & $\begin{array}{l}52 \cdot 0 \\
62 \cdot 8^{\star} \\
87 \cdot 3^{\star} \\
31 \cdot 5^{\star} \\
71 \cdot 6 \\
65 \cdot 8 \\
72 \cdot 5 \\
87 \cdot 9 \\
91 \cdot 1 \\
88 \cdot 8 \\
81 \cdot 5 \\
68 \cdot 8 \\
83 \cdot 0 \\
65 \cdot 1 \\
67 \cdot 2^{\star} \\
65 \cdot 1^{\star} \\
73 \cdot 9 \\
70 \cdot 0 \\
90 \cdot 0 \\
82 \cdot 0 \\
90 \cdot 3^{\star} \\
87 \cdot 3^{\star} \\
62 \cdot 6^{\star} \\
55 \cdot 6^{\star} \\
86 \cdot 7^{\star} \\
73 \cdot 7^{\star}(14 \cdot 6)\end{array}$ \\
\hline Mean (SD) & $60 \cdot 8(18 \cdot 4)$ & $78 \cdot 7(8 \cdot 5)$ & $48 \cdot 9(20 \cdot 6)$ & $73 \cdot 7(14 \cdot 6)$ \\
\hline
\end{tabular}

$\star$ Denotes patient with active disease.

(Table V, Fig 6). These results were obtained from 17 assays with autologous serum and 14 with crossed serum at the 30 minute time point. At 60 minutes two plates from each group were unsuitable for counting so that 15 and 12 results respectively were available for analysis.

\section{PHAGOCYTOSIS}

Normal neutrophils incorporated a mean (SD) of $2 \cdot 0(0.98) C$ albicans and Crohn's disease neutrophils a mean (SD) of $1.9(0.88) C$ albicans (Table VI, Fig 7). These results are not significantly different.

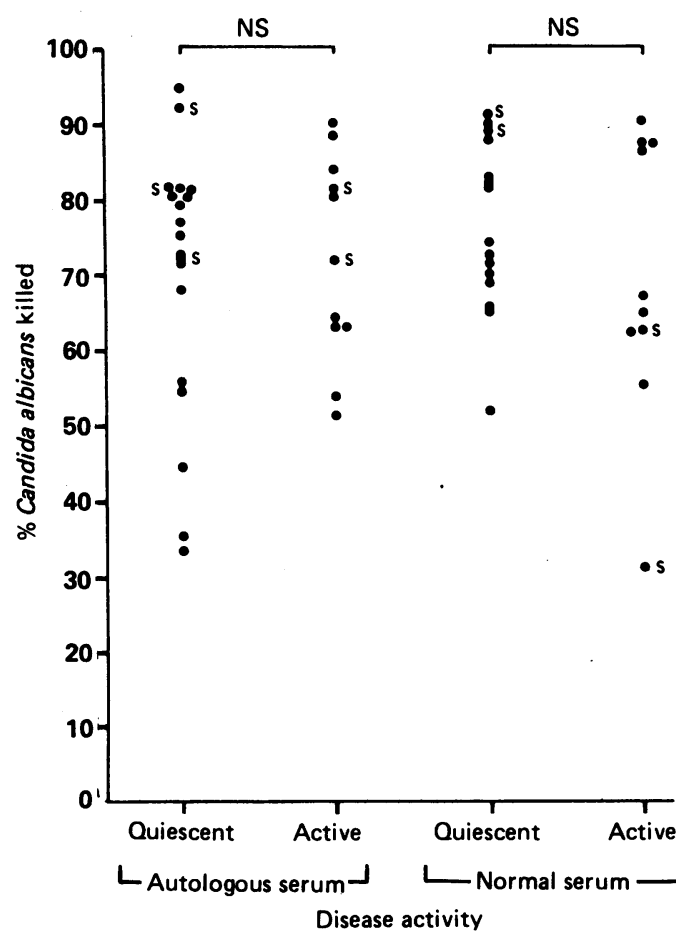

Figure 5: Crohn's disease neutrophil candidacidal activity at 60 minutes related to disease activity. 's' denotes patient on steroids. 
TABLE V Candidacidal activity of serum

\begin{tabular}{|c|c|c|c|c|}
\hline & \multicolumn{2}{|l|}{ Normal serum } & \multicolumn{2}{|l|}{ Crohn's serum } \\
\hline & $30 \mathrm{~min}$ & $60 \min$ & $30 \min$ & $60 \min$ \\
\hline & $84 \cdot 1$ & $76 \cdot 4$ & $108 \cdot 0$ & $88 \cdot 4$ \\
\hline & 70.0 & $78 \cdot 0$ & 96.9 & 90.0 \\
\hline & $76 \cdot 8$ & $56 \cdot 4$ & $94 \cdot 7$ & $105 \cdot 3$ \\
\hline & 95.5 & $67 \cdot 7$ & $96 \cdot 7$ & $100 \cdot 8$ \\
\hline & 96.9 & $94 \cdot 2$ & $107 \cdot 1$ & $107 \cdot 1$ \\
\hline & $83 \cdot 2$ & $87 \cdot 4$ & $96 \cdot 2$ & $97 \cdot 7$ \\
\hline & $100 \cdot 0$ & $97 \cdot 2$ & $87 \cdot 7$ & 85.9 \\
\hline & 97.5 & 111.6 & $95 \cdot 1$ & $91 \cdot 3$ \\
\hline & 119.6 & $107 \cdot 7$ & $87 \cdot 1$ & 91.0 \\
\hline & $98 \cdot 5$ & 110.0 & $91 \cdot 3$ & 90.4 \\
\hline & $95 \cdot 3$ & $83 \cdot 0$ & 100.0 & $84 \cdot 1$ \\
\hline & $101 \cdot 2$ & $101 \cdot 7$ & 89.9 & $73 \cdot 5$ \\
\hline & 78.8 & $91 \cdot 3$ & $99 \cdot 1$ & NA \\
\hline & $100 \cdot 0$ & $100 \cdot 4$ & $117 \cdot 8$ & $\mathrm{NA}$ \\
\hline & $104 \cdot 2$ & 116.5 & & \\
\hline & $88 \cdot 3$ & NA & & . \\
\hline Mean (SD) & $\begin{array}{l}60.1 \\
91.2(14 \cdot 3)\end{array}$ & $\begin{array}{l}\text { NA } \\
97.7(8.5)\end{array}$ & $92 \cdot 0(17 \cdot 2)$ & $92 \cdot 1(9 \cdot 4)$ \\
\hline
\end{tabular}

NA $=$ Not available.

\section{Discussion}

Two previous studies have investigated microbicidal activity in Crohn's disease with conflicting results. Lamster et $a l^{11}$ reported one patient whose neutrophils showed an enhanced ability to phagocytose and lyse Escherichia coli compared to a single control subject. Worsaae $e t$ $a l^{12}$ investigated nine patients and found an 'increased intracellular survival' of Staphylococcus aureus in Crohn's disease neutrophils. The importance of this finding is uncertain since staphylococci do not form granulomas and patients with Crohn's disease are not unusually susceptible to bacterial infections.

Lehrer and Cline ${ }^{13}$ first showed in vitro the phagocytosis and killing of $C$ albicans by human neutrophils and monocytes. The process is rapid; more than $90 \%$ of $C$ albicans injected into the bloodstream of rabbits is removed within 10 minutes ${ }^{14}$ and more than $70 \%$ is removed within five minutes from the blood stream of rats. ${ }^{\text {is }}$ The yeast are killed intracellularly by the phagocyte peroxide/myeloperoxidase system ${ }^{16-18}$ and a nonoxidative fungicidal mechanism. ${ }^{16} 18$ There are no reports of candidacidal activity in patients with inflammatory bowel disease, but neutrophil myeloperoxidase is probably normal in Crohn's disease. ${ }^{19}$

A Candida/neutrophil ratio of $1: 1$ was used in

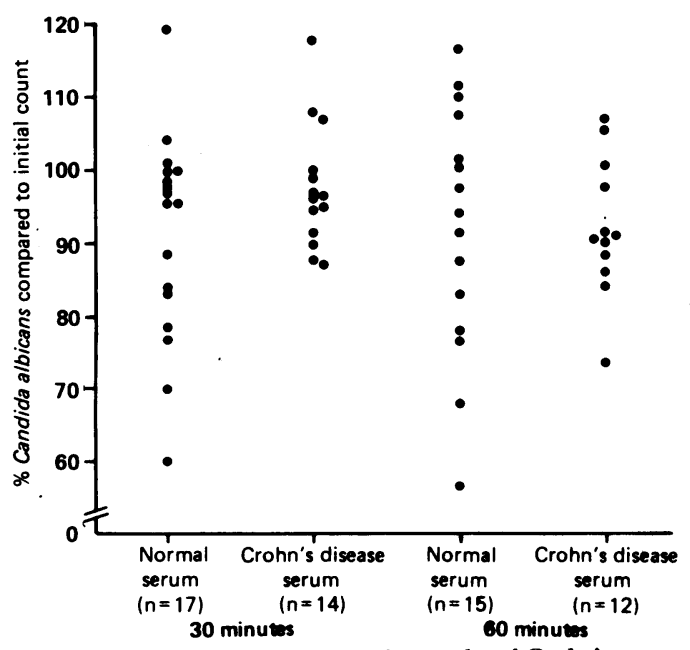

Figure 6: Candidacidal activity of normal and Crohn's disease serum.
TABLE VI Phagocytic index

\begin{tabular}{lll}
\hline & Normal & Crohn's disease \\
\hline 2.5 & 1.1 \\
1.5 & 1.0 \\
1.8 & 1.3 \\
1.7 & 1.4 \\
1.4 & 1.2 \\
2.0 & 2.4 \\
2.7 & 1.9 \\
2.5 & 2.3 \\
1.8 & 2.2 \\
3.5 & 1.3 \\
0.8 & 3.3 \\
0.7 & 2.6 \\
1.6 & 3.2 \\
0.4 & 3.7 \\
0.7 & 0.3 \\
& 2.3 & 1.5 \\
& 3.9 & 2.8 \\
& 2.3 & 1.5 \\
Mean (SD) & 2.7 & 1.9 \\
& 3.5 & 1.3 \\
& $2.0(0.98)$ & $1.9(0.88)$
\end{tabular}

the assay, as recommended by Babior and Cohen, ${ }^{7}$ since the number of Candida presented to neutrophils and the number killed is linear up to a ratio of $5: 1 .^{20}$

These results suggest that neutrophils from patients with Crohn's disease have a significantly impaired candidacidal activity in vitro, even in quiescent disease, implying that patients with Crohn's disease are less able to inactivate organisms which can cause chronic inflammatory diseases. The results are not due to a serum inhibitor since adding Crohn's disease serum to washed normal neutrophils did not impair their candidacidal activity. The temporary improvement in killing by Crohn's disease neutrophils in the presence of normal serum at 30 minutes but not at 60 minutes may suggest some replenishment of a deficient plasma factor important for killing. If it was due to poor opsonisation the improvement should have been sustained and Crohn's disease serum should have impaired the candidacidal activity of normal neutrophils.

Phagocytosis was studied because any impairment in opsonisation or the ability of Crohn's

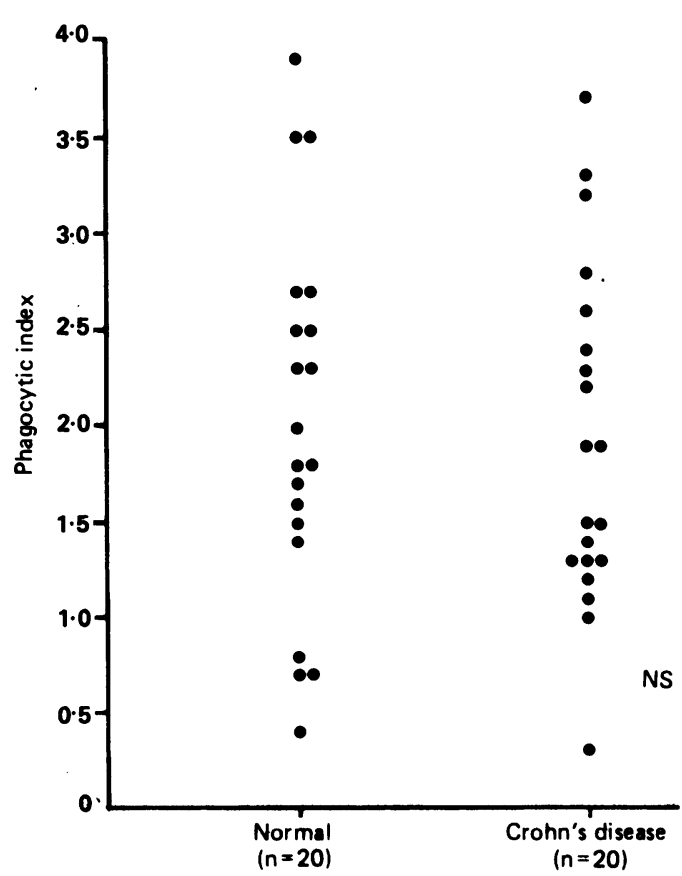

Figure 7: Neutrophil phagocytosis of Candida albicans. 
disease neutrophils to phagocytose would result in impaired killing ability. A radiometric assay was used, ${ }^{20}{ }^{21}$ based on the observations that the uptake of ${ }^{3} \mathrm{H}$-uridine by Candida is an index of phagocytic function, that there is linear correlation between uridine incorporation and yeast numbers, and that neutrophils do not take up uridine in short term cultures so that candida within neutrophils have no access to uridine. ${ }^{21}$ The assay is one of the best available for measuring phagocytosis and opsonisation, ${ }^{22} 23$ and no abnormality was found.

There was no evidence that normal or Crohn's disease serum alone had candidacidal activity, a mean of $92 \%$ of $C$ albicans remaining after one hour. This confirms the findings of Wilkinson, ${ }^{24}$ who reported that less than $10 \%$ of organisms should be dead after one hour. Some counts were greater than $100 \%$, presumably because Candida continued to multiply during the assay - serum at $37^{\circ} \mathrm{C}$ is a good stimulant of Candida germ tube formation. ${ }^{25} 26 \mathrm{~A}$ few counts in normal serum were quite low at 30 and 60 minutes, due either to a sampling error or to the presence in serum of antibodies to Candida which result from the host's immune response to infection. There is no good published evidence for true fungistasis of C albicans by serum. ${ }^{3}$

Many factors can affect neutrophil function and in patients with Crohn's disease malnutrition is an important consideration. We, however, found similar results in patients with quiescent and active disease and know of no data suggesting that patients in a quiescent phase of their disease are malnourished. Hill et al found that malnutrition was unlikely to be present when patients with inflammatory bowel disease were in remission or during the early stages of an acute attack. ${ }^{27}$ Deficiency of micronutrients, such as iron, necessary for normal neutrophil function is unlikely to have caused the impaired killing since iron is an essential growth factor for $C$ albicans. Iron deficiency offers a competitive advantage to the host rather than the organism because iron binding to transferrin and lactoferrin renders the level of free ionic iron too low for microbial growth. ${ }^{28}$ The growth of $C$ albicans in human serum is directly related to the percentage of iron saturation ${ }^{30}$ and iron deficiency increases resistance to $C$ albicans in vivo. ${ }^{31}$ If our patients were iron deficient the killing of Candida would have been greater than that in normal subjects.

An unexplained finding is that some patients had normal neutrophil candidacidal activity, as shown by the overlapping results in Figures 2 and 3. The reason is not clear but the results imply that the defect is either intermittent or occurs only in certain patients, but these were not necessarily patients with quiescent disease or those on a particular treatment.

Neutrophils from many patients with Crohn's disease have an impaired ability to kill C albicans, an organism known to cause chronic inflammatory diseases. There was no evidence of a serum inhibitor, defective opsonisation, or impaired phagocytosis, and a cellular defect is the most likely explanation. Further work is needed to determine the reason for these findings and whether they are disease specific.

1 Hermanowicz A, Gibson PR, Jewell DP. The role of phagocytes in inflammatory bowel disease. Clin Sci 1985; 69: 241-9.

2 Finegold SM, Sutter VL, Mathisen GE. Human intestinal microflora in health and disease. London: Academic Press, microflor

3 Odds FC. Candida and candidosis. 2nd ed. London: Baillière Tindall, 1988

4 Kozinn PJ, Taschdjian CL. Enteric candidiasis: diagnosis and clinical considerations. Pediatrics 1962; 30: 71-85.

5 Alexander JG. Allergy in the gastrointestinal tract. Lance 1975; ii: 1264 .

6 Holti G. Candida allergy. In: Winner HI, Hurley R, eds Symposium on candida infections. London: Livingstone, 1966: 73-81.

7 Babior BM, Cohen HJ. Measurement of neutrophil function In: Cline MJ, ed. Leukocyte function. London: Churchill Livingstone, 1981: 1-38.

8 Giddings JC, Piovella F, Ricetti M, Jarvis A, Peake IR, Bloom AL. Characterization of procoagulant activity produced by cultures of human monocytes and lymphocytes separated in cultures of human monocytes and lymphocytes separated in Haematol 1980; 2: 121-8.

9 Jepsen LV, Skottun T. A rapid one-step method for the isolation of human granulocytes from whole blood. Scand $\mathcal{F}$ Clin Lab Invest 1982; 42: 235-8.

10 Harvey RF, Bradshaw JM. A simple index of Crohn's-diseas activity. Lancet 1980; i: 514

11 Lamster I, Sonis S, Hannigan A, Kolodkin A. An association between Crohn's disease, periodontal disease and enhanced neutrophil function. I Periodontol 1978; 49: 475-9.

12 Worsaae N, Staehr Johansen K, Christensen KC. Impaired in vitro function of neutrophils in Crohn's disease. Scand $\mathcal{F}$ vitro function of neutrophil

13 Lehrer RI, Cline MJ. Interaction of Candida albicans with human leukocytes and serum. $\mathcal{F}$ Bacteriol 1969; 98: 996 1004.

14 Baine WB, Koenig MG, Goodman JS. Clearance of Candida albicans from the bloodstream of rabbits. Infect Immun 1974 10: $1420-5$.

15 Jeunet FS, Meuwissen HJ, Good RA. Fate of Candida albican in neonatally thymectomized rats. Proc Soc Exp Biol Med 1970; 133: 53-6.

16 Brune K, Schmid L, Glatt M, Minder B. Correlation between antimicrobial activity and peroxidase content of leukocytes. Nature 1973; 245: 209-10.

17 Klebanoff SJ. Myeloperoxidase: contribution to the microbicidal activity of intact leukocytes. Science 1970; 169: 1095-7.

18 Lehrer RI. Measurement of candidacidal activity of specific leukocyte types in mixed cell populations. I. Normal, leukocyte types in mixed cell populations. I. Normal, myeloperoxidase-deficient, and chronic granul

19 Renz M, Ward M, Eastwood MA, Harkness RA. Neutrophil function and myeloperoxidase activity in inflammatory bowel disease. Lancet 1976; ii: 584 .

20 Bridges CG, Dasilva GL, Yamamura M, Valdimarsson H. A radiometric assay for the combined measurement of phagocytosis and intracellular killing of Candida albicans. Clin Ex Immunol 1980; 42: 226-33.

21 Yamamura M, Boler J, Valdimarsson $\mathrm{H}$. Phagocytosis measured as inhibition of uridine uptake by Candida albicans. F Immunol Methods 1977; 14: 19-24.

22 Axtell RA. Evaluation of the patient with a possible phagocytic disorder. Hematol Oncol Clin North Am 1988; 2: 1-12.

23 Rajkovic IA, Williams R. Rapid microassays of phagocytosis, bacterial killing, superoxide and hydrogen peroxide production by human neutrophils in vitro. F Immunol Methods 1985; 78: $35-47$.

24 Wilkinson PC. In: Thompson RA, ed. Techniques in clinical immunology. 2nd ed. London: Blackwell, 1981: 273-93.

25 Barlow AJE, Aldersley T, Chattaway FW. Factors present in serum and seminal plasma which promote germ-tube formation and mycelial growth of Candida albicans. $\mathcal{F}$ Gen Microbiol 1974; 82: 261-72.

26 Dolan CT, Ihrke DM. Further studies of the germ-tube test for Candida albicans identification. Am f Clin Pathol 1971; 55: 733-4.

27 Hill GL, Blackett RL, Pickford IR, Bradley JA. A survey of protein nutrition in patients with inflammatory bowel protein nutrition in patients with inflammatory bowel disease - a rational

28 Finkelstein RA, Sciortino CV, McIntosh MA. Role of iron in microbe-host interactions. Rev Infect Dis 1983; 5: S759-77.

29 Weinberg ED. Iron witholding: a defence against infection and neoplasia. Physiol Rev 1984; 64: 62-102.

30 Elin RJ, Wolff SM. Effect of $\mathrm{pH}$ and iron concentration on growth of Candida albicans in human serum. $\mathcal{F}$ Infect Dis 1973; 127: 705-8.

31 Elin RJ, Wolff SM. The role of iron in nonspecific resistance to infection induced by endotoxin. $\mathcal{F}$ Immunol $1974 ; 112$ : 737 45. 